\title{
Biological parameters of Amblyomma coelebs Neumann, 1906 (Acari: Ixodidae) under experimental conditions
}

\section{Parâmetros biológicos de Amblyomma coelebs Neumann, 1906 (Acari: Ixodidae) em condiçóes experimentais}

\author{
André de Abreu Rangel Aguirre ${ }^{1,2}$; Vinicius da Silva Rodrigues ${ }^{1,3}$; Ivaneide Nunes da Costa ${ }^{4}$; Marcos Valerio Garcia ${ }^{3,5}$; \\ Leandro de Oliveira Souza Higa ${ }^{1,3}$; Jansen Fernandes Medeiros ${ }^{2}$; Renato Andreotti ${ }^{1,3 *}$ \\ ${ }^{1}$ Pós-graduação em Doenças Infecciosas e Parasitárias - FAMED, Universidade Federal do Mato Grosso do Sul - UFMS, \\ Campo Grande, MS, Brasil \\ ${ }^{2}$ Laboratório de Entomologia, Fundação Oswaldo Cruz - FIOCRUZ, Porto Velho, RO, Brasil \\ ${ }^{3}$ Laboratório de Biologia do Carrapato, Empresa Brasileira de Pesquisa Agropecuária - EMBRAPA Gado de Corte, \\ Campo Grande, MS, Brasil \\ ${ }^{4}$ Programa de Pós-graduação em Biologia Experimental, Universidade Federal de Rondônia - UNIR, Porto Velho, RO, Brasil \\ ${ }^{5}$ Programa de Desenvolvimento Científico Regional - DCR, Fundação de Apoio ao Desenvolvimento do Ensino, Ciência e \\ Tecnologia - FUNDECT, Governo do Estado de Mato Grosso do Sul, Campo Grande, MS, Brasil
}

Received November 10, 2017

Accepted January 11, 2018

\begin{abstract}
One generation of Amblyomma coelebs life cycle under experimental conditions was evaluated. Ten tick pairs were allowed to feed on rabbits under laboratory conditions (LC), resulting six engorged females with a mean weight of $1,403.9 \mathrm{mg}$. Two females were maintained in a forest reserve under natural conditions (NC), and four were maintained in incubators (LC). The engorgement period lasted 10.33 days. Pre-oviposition periods were 10.75 (NC) and 22 days (LC). The mean egg-mass weight was $514.76 \mathrm{mg}$, and the blood meal conversion index was $36.67 \%$ (LC). Incubation period under NC and LC were 91 and 56.33 days and hatching rates were $50 \%$ and 28.33\%, respectively. Larval engorgement period ranged from 4 to 10 days, with average weight of $1.1 \mathrm{mg}$. Engorged larvae were incubated under NC and LC, with a premolt period of 27 to 36 days and molting rate of $7.1 \%$ and $28.7 \%$, respectively. Nymphal engorgement period ranged from 5 to 7 days, with a mean weight of $18.8 \mathrm{mg}$ and a recovery rate of $54.54 \%$. In LC, the ecdysis mean period was 24.5 days, and molting rate was $44.44 \%$, resulting in 24 adult $A$. coelebs. Our results show a life cycle of 187.45 (NC) and 149 (LC) days.
\end{abstract}

Keywords: Amblyomma coelebs, life cycle, biological parameters, experimental conditions, rabbits.

\section{Resumo}

Uma geração do ciclo de vida de Amblyomma coelebs em condiçôes laboratoriais foi avaliada. Dez casais de carrapatos foram alimentados em coelhos sob condiçóes laboratoriais (CL), resultando em seis fêmeas ingurgitadas, com um peso médio de 1.403,9 miligramas (mg). Duas fêmeas foram mantidas em uma reserva florestal sob condiçóes naturais $(\mathrm{CN})$, e quatro foram mantidas em incubadoras (CL). O período de ingurgitamento durou 10,33 dias. Períodos de pré-postura foram de 10,75 (CN) e 22 dias (CL). O peso médio das massas de ovos foi de 514,76 mg e o índice de conversão alimentar foi de 36,67\% (CL). O período de incubação em CN e CL foi de 91 e 56,33 dias e os percentuais de eclosão foram de $50 \%$ e $28,33 \%$, respectivamente. O período de ingurgitamento larval variou de quatro a 10 dias, com peso médio de 1,1 mg. Larvas ingurgitadas foram incubadas em CN e CL, com período de pré-muda de 27 a 36 dias e percentual de ecdise de $7,1 \%$ e $28,7 \%$, respectivamente. O período de ingurgitamento das ninfas oscilou de cinco a sete dias, com peso médio de 18,8 mg e uma taxa de recuperação de 54,54\%. Em CL, o período médio de ecdise foi de 24,5 dias, e o percentual de muda foi $44,44 \%$, resultando em 24 adultos de $A$. coelebs. Estes resultados demonstram um ciclo de vida de $187,45(\mathrm{CN})$ e 149 (CL) dias.

Palavras-chaves: Amblyomma coelebs, ciclo de vida, parâmetros biológicos, condiçóes experimentais, coelhos.

\footnotetext{
*Corresponding author: Renato Andreotti. Embrapa Gado de Corte, Avenida Rádio Maia, no 830, CEP 79106-550, Campo Grande, MS, Brasil.

e-mail: renato.andreotti@embrapa.br
} 


\section{Introduction}

Amblyomma coelebs Neumann is one of the 71 species composing the Brazilian tick fauna, which included 46 species from the Ixodidae family and 25 from the Argasidae family (KRAWCZAK et al., 2015; LABRUNA et al., 2016; WOLF et al.; 2016; MUÑOZ-LEAL et al., 2017). Amblyomma coelebs is geographically distributed in Neotropical and Nearctic regions (ONOFRIO et al., 2006). In Brazil, it has been reported to occur in the states of São Paulo, Minas Gerais, Mato Grosso do Sul, Paraná, Rondônia, Acre, Mato Grosso, Roraima, Pará and Espírito Santo (GUIMARÃES et al., 2001; LABRUNA et al., 2002b, 2004b; ARZUA et al., 2005; SARAIVA et al., 2012).

Adults of this species prefer parasitizing tapirs (Tapirus terrestris) (LABRUNA \& GUGLIELMONE, 2009; GUGLIELMONE et al., 2014) but can also be found parasitizing equines (BELDOMÉNICO et al., 2003). They have also been found parasitizing other mammals and birds (OGRZEWALSKA et al., 2010; NAVA et al., 2017; LOPES et al., 2016). Nymphs appear to be more generalists and exploit a larger host range that includes carnivores, marsupials, rodents, birds and, occasionally, humans (BELDOMÉNICO et al., 2003; SPONCHIADO et al., 2015; GARCIA et al., 2015; OGRZEWALSKA \& PINTER, 2016; OGRZEWALSKA et al., 2009; 2010; ITO et al., 2017).

The importance of this tick as a pathogen vector has been described by Labruna et al. (2004b), who in a study of ixodid species with Rickettsia infections found that $A$. coelebs may be a carrier of Rickettsia amblyommatis, formerly known as "Candidatus Rickettsia amblyommii" (KARPATHY et al., 2016), as also reported by Silveira et al. (2015). The pathogenicity of this Rickettsia species is still uncertain (NAVA et al., 2017), but findings from these studies suggest that $A$. coelebs is a possible vector and may be a carrier of other agents with zoonotic potential for animals and humans.

In view of this information, there is a need for a better understanding of the biological aspects of this species under experimental conditions and its relationships with its hosts.

\section{Materials and Methods}

\section{Study location and animal use}

The study was carried out in the Tick Biology Laboratory (Laboratório de Biologia do Carrapato) in the Animal Health

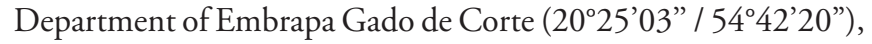
Campo Grande, Mato Grosso do Sul, Brazil.

The Ethics Commission on the Use of Animals (CEUA) at the Federal University of Mato Grosso do Sul (UFMS) approved this study under protocol number 699/2015.

\section{Tick collection}

Twelve adult $A$. coelebs (four female and eight male) were captured using dry ice traps $\left(\mathrm{CO}_{2}\right)$ as described by Oliveira et al. (2000), and fourteen ticks (seven female and seven male) were captured using the cloth dragging technique (RECHAV, 1982). These free-living ticks were captured in a forest reserve belonging to the Embrapa Gado de Corte experimental farm in the municipality of Terenos (20³3'11.7” S / 5448’49.0” W), Mato Grosso do Sul, Brazil.

After capture, the ticks were placed in tubes with perforated tops, transported to the Tick Biology Laboratory and identified according to the dichotomous key proposed by Barros-Battesti et al. (2006).

\section{Experimental infestation with adult $A$. coelebs}

Six New Zealand rabbits (Oryctolagus cuniculus) with no previous tick contact and of undetermined sex were used for infestation. Rabbits were chosen as the experimental host because they are easy to acquire and to handle in the laboratory. In addition, juvenile instars of various tick species are known to parasitize small mammals (TATCHELL, 1987). Tick feeding chambers were used following the technique previously described by Szabó et al. (1995). Two rabbits were infested with $A$. coelebs. Five pairs of adult ticks were placed in separate feeding chambers on each rabbit.

\section{Recovery of engorged females}

Six engorged female ticks were collected after completing their blood meal. They were placed into individual tubes with perforated tops, weighed individually and divided into two groups:

Group 1: Four engorged females were maintained in B.O.D. incubators at $28^{\circ} \mathrm{C}\left(82.4^{\circ} \mathrm{F}\right)$ and $80 \%$ humidity in individual tubes with perforated tops (laboratory conditions; LC).

Group 2: Two engorged females were packed into cylindrical stainless steel wire tubes $\left(60 \mathrm{mesh} / \mathrm{cm}^{2}, 61 \mathrm{~mm}\right.$ length, $37 \mathrm{~mm}$ diameter) that were sealed with rubber stoppers. The females were taken to a riparian forest reserve located within the Embrapa Gado de Corte in Campo Grande in July (07/16/2016). The tubes were placed horizontally on the soil surface along the roots of vegetation. The area was on the edge of a stream under dense vegetation and had a high humidity (natural conditions; NC). The temperature and humidity at the site were measured daily using a thermo-hygrometer (Highmed) to record maximum and minimum values. The thermos-hydrometer was placed in contact with the ground.

\section{Infestation with $A$. coelebs larvae and nymphs}

Approximately 2,200 larvae were used to infest two rabbits in individual feeding chambers. All larvae used in experimental infestations were between 15 and 25 days old. After their blood meal, engorged larvae were collected daily from the chambers, counted and weighed. Engorged larvae were separated into two lots: Lot 1 was composed of 113 larvae that were taken to the forest reserve (NC) in November (11/21/2016); and Lot 2 was composed of 317 larvae that were maintained in B.O.D. incubators (LC) $\left(28^{\circ} \mathrm{C}, 80 \%\right.$ relative humidity, $12: 12$ light: dark $)$ until ecdysis.

A total of 99 nymphs developed from the larvae maintained in the laboratory and in the forest reserve, which were used to infests two rabbits. The chambers were monitored daily, and 
engorged nymphs were collected, individually weighed, placed in vials and taken to the laboratory, where they were held in B.O.D incubators for posterior ecdysis.

\section{Biological parameters evaluated}

The recovery rate, engorgement period, engorged female weight, pre-oviposition period, egg-mass weight, blood meal conversion index (BENNETT, 1974), egg incubation period and hatching rate, determined by visual estimation (LABRUNA et al., 2000), were evaluated. The egg-mass weight and blood meal conversion index were not determined in the engorged female ticks allocated to the NC treatment because we decided not to manipulate them to prevent stress, death and egg desiccation.

For larval and nymphal instars, the following parameters were measured following the methods described by Sanches et al. (2008) and Szabó et al. (2009): period of engorgement, weight, molting duration, recovery rate and molting success rate.

\section{Results}

The biological parameters measured in $A$. coelebs are presented in Tables 1, 2 and 3.

The mean engorgement period of $A$. coelebs females was 10.33 days; after the blood meal, six engorged ticks were recovered (60\% recovery rate), with an average weight of $1,403.91 \mathrm{mg}$. The pre-oviposition periods of engorged females under natural (NC) and laboratory (LC) conditions were 22 and 10.75 days, respectively. The mean egg-mass weight was $514.76 \mathrm{mg}$, and the blood meal conversion index was $36.67 \%$ under LC. Incubation periods for the eggs maintained in NC and LC were 91 and 56.33 days, respectively, and the larval hatching rates were $50 \%$ and $28.33 \%$, respectively (Table 1 ).

Only one engorged female tick recovered and maintained under NC oviposited, and larvae were subsequently obtained from these eggs. Only one engorged female tick maintained under LC died after initiating oviposition, while the others successfully completed oviposition (Table 1).

The larval engorgement period ranged from 4 to 10 days. The mean weight of larvae was $1.1 \mathrm{mg}$, and the recovery rate was $19.54 \%$. The molting success rates for nymphs were $7.1 \%$ and 28.7\%, under NC and LC, respectively. Biological parameters for larvae are shown in Table 2.

A total of 99 nymphs were obtained from engorged larvae maintained under NC (8) and LC (91). Fed nymphs showed an engorgement period ranging from 5 to 7 days, a mean weight of $18.8 \mathrm{mg}$ and a recovery rate of $54.54 \%$ (54 engorged nymphs). All nymphs were maintained under LC. The duration of the molting process was 24.5 days, and the molting success rate was $44.44 \%$, resulting in 24 adult ticks (Table 3 ).

\section{Discussion}

We present, for the first time, the biological parameters of the life cycle of $A$. coelebs when allowed to engage in natural feeding behaviors on laboratory hosts (New Zealand rabbits) and maintained under experimental conditions (NC and LC).

The adult phase of $A$. coelebs was able to exploit rabbits as an experimental host, and the ticks were able to successfully engorge, as demonstrated by the recovery rate of engorged females, their mean weight and the mean egg-mass weight. However, some

Table 1. Mean, Standard Deviation and Amplitude (in parentheses) related to the biological parameters of Amblyomma coelebs female ticks in laboratory condition (LC) and natural condition (NC) in Campo Grande, MS, Brazil.

\begin{tabular}{cccccccc}
\hline $\begin{array}{c}\text { Biological } \\
\text { parameters }\end{array}$ & $\begin{array}{c}\text { E.P.* } \\
\text { (days) }\end{array}$ & $\begin{array}{c}\text { E.F.W.* } \\
(\mathbf{m g})\end{array}$ & $\begin{array}{c}\text { P.O.P } \\
\text { (days) }\end{array}$ & $\begin{array}{c}\text { E.M.W. } \\
(\mathbf{m g})\end{array}$ & $\begin{array}{c}\text { F.C.R. } \\
(\%)\end{array}$ & $\begin{array}{c}\text { Inc.P. } \\
(\text { days })\end{array}$ & $\begin{array}{c}\text { L.H.R. } \\
(\%)\end{array}$ \\
\hline Laboratory (LC) & $10.33 \pm 1.36$ & $1403.91 \pm 574.72$ & $10.75 \pm 1.70$ & $514.76 \pm 364.9$ & $36,67 \pm 9.35$ & $56.33 \pm 11.37$ & $28.33 \pm 36.17$ \\
$(8-12)$ & $(544-2146.9)$ & $(9-13)$ & $(175-905.5)$ & $(32.2-50)$ & $(47-69)$ & $(5-70)$ \\
Natural (NC) & & & $22 \pm 0(22)$ & - & - & $91 \pm 0(91)$ & $50 \pm 0(50)$
\end{tabular}

- Values not obtained; E.P. = Engorgement Period (days); E.F.W . = Engorged Female Weight (mg); P.O.P = Pre-oviposition Period (days); E.M.W.= Egg Mass Weight $(\mathrm{mg}) ;$ F.C.R. = Feed Covertion Ratio (\%); Inc.P. = Incubation period (days); L.H.R. = Larvae Hatching Rate (\%). *Parameteres "E.P." and "E.F.W." both performed only in laboratory conditions.

Table 2. Mean, Standard Deviation and Amplitude (in parentheses) related to the biological parameters of Amblyomma coelebs larvae fed on rabbit and maintained in laboratory condition (LC) and natural condition (NC) in Campo Grande, MS, Brazil.

\begin{tabular}{ccccc}
\hline $\begin{array}{c}\text { Biological } \\
\text { parameters }\end{array}$ & $\begin{array}{c}\text { E.P.* } \\
\text { (days) }\end{array}$ & $\begin{array}{c}\text { Weight } \\
(\mathbf{m g})^{*}\end{array}$ & $\begin{array}{c}\text { P.M.P. } \\
\text { (days) }\end{array}$ & $\begin{array}{c}\text { M.S. } \\
(\%)\end{array}$ \\
\hline Laboratory (LC) & $5.62 \pm 1.62(4-10)$ & $1.11 \pm 0.17(0.7-1.5)$ & 36 & 28.7 \\
Natural (NC) & & & $28 \pm 1(27-29)$ & 7.1 \\
\hline
\end{tabular}

E.P. = Engorgement Period; P.M.P. = Premolt period; M.S. = molting success. *Parameteres "E.P." and "Weight" both performed only in laboratory conditions.

Table 3. Mean, Standard Deviation and Amplitude (in parentheses) related to the biological parameters of Amblyomma coelebs nymphs in laboratory conditions, Campo Grande, MS, Brazil.

\section{Biological Parameters}

\begin{tabular}{cccccc}
\hline $\begin{array}{c}\text { Number of } \\
\text { exposed nymphs }\end{array}$ & $\begin{array}{c}\text { Number of nymphs } \\
\text { that engorged }\end{array}$ & $\begin{array}{c}\text { Engorgement Period } \\
(\text { days })\end{array}$ & $\begin{array}{c}\text { Weight } \\
(\mathbf{m g})\end{array}$ & $\begin{array}{c}\text { Pre-molt period } \\
(\text { days })\end{array}$ & $\begin{array}{c}\text { Molting success } \\
(\%)\end{array}$ \\
\hline 99 & $54(54.54 \%)$ & $6 \pm 1.41(5-7)$ & $18.8 \pm 10.2(11,6-26,03)$ & $24.5 \pm 2.12(23-26)$ & 44.44 \\
\hline
\end{tabular}


difficulties were observed in the subsequent developmental stages of the life cycle of this species.

Difficulties have also been reported by other authors for several tick species, which has required the use of hosts either similar to or different than the natural hosts to facilitate the successful rearing of ticks and maintenance of colonies; this can alter the duration of the life cycle in some species (e.g., in Argasidae and Ixodidae) (RODRIGUES et al., 2002; LABRUNA et al., 2002b; SANCHES et al., 2008; OLEGÁRIO et al., 2011).

The use of rabbits as alternative hosts is a well-established method for the maintenance of colonies of diverse tick species of the genera Amblyomma, Rhipicephalus, Ixodes, Dermacentor, and Haemaphysalis. Rabbits are easy to maintain and handle in the laboratory, and it is easy for juvenile instars of certain tick species to successfully parasitize them (GUGLIELMONE et al., 1991; MANGOLD \& GUGLIELMONE, 1993; BECHARA et al., 1995; TROUGHTON \& LEVIN, 2007; RODRIGUES et al., 2017).

In this study, we attributed some of the difficulties in perpetuating several generations of $A$. coelebs to issues related to egg incubation, the low rate of recovery for engorged larvae and the death of larva. Most of the tick eggs became desiccated, preventing larva from hatching. A considerable number of engorged larvae died under conditions where the temperature and humidity were controlled and in the natural environment. Considering the results presented here, the abiotic conditions were not ideal for some stages of the tick life cycle; however, the conditions were satisfactory for the analysis of the biological parameters we assessed. The engorged larvae allocated to the $\mathrm{NC}$ were introduced in the transition period between spring and summer, which is a period with hot and humid days and high light levels, which is theoretically unfavorable for this instar stage: according to Labruna et al. (2002a, 2003a), from studies on the population dynamics of Amblyomma sculptum (published as Amblyomma cajennense), conditions corresponding to those that occur in November are only favorable for adult ticks of the genus Amblyomma in Brazil.

These observations corroborate the data presented by Szabó et al. (2009) in a study of the life cycle of $A$. incisum. These authors changed their protocol to include a natural reserve area in the study in an attempt to observe some of the biological parameters of this tick species. In the current study, due to the difficulties of observing some of the biological parameters of the tick free-living stage, we attempted to maintain $A$. coelebs in a natural environment as described by Szabó et al. (2009).

Maintaining abiotic factors such as temperature, humidity and photoperiod within acceptable ranges is fundamental for the maintenance of tick colonies. Most studies concerning the maintenance of ticks under controlled conditions report temperatures varying from 27 to $29^{\circ} \mathrm{C}$ and a range of relative humidity values between 70 and 90\% (BECHARA et al., 1995; RODRIGUES et al., 2002; LABRUNA et al., 2002a, 2003a; SZABÓ et al., 2009; OLEGÁRIO et al., 2011), which is in agreement with the methodology of the current study as we maintained a temperature of $28^{\circ} \mathrm{C}$ and a relative humidity of least $80 \%$ for ticks raised under LC.

The average ambient temperatures for engorged female ticks and engorged larvae under NC (forest) were $25^{\circ} \mathrm{C}$ and $28^{\circ} \mathrm{C}$, respectively. However, because the area is near a stream, the relative humidity for the two periods ranged from 75 to $90 \%$. It is important to keep in mind that the experimental ticks were, at least theoretically, in a favorable microenvironment, with suitable temperatures and humidity due to the abiotic effects of the forest and river. This area is also a natural habitat and part of the ecosystem of the tick's main host, the tapir (unpublished data).

Life cycles, under laboratory conditions, of other tick species which parasite tapirs were already described, such as Amblyomma ovale (MARTINS et al., 2012), Amblyomma dubitatum (published as Amblyomma cooperi- LABRUNA et al., 2004a), Amblyomma triste (LABRUNA et al., 2003b) and Amblyomma oblongoguttatum (MARTINS et al., 2017). When fed on rabbits, larvae of $A$. triste, $A$. ovale and $A$. oblongoguttatum present a recovery rate lower than $20 \%$, a value similar to the one obtained on this study. For nymphs, on the same host species, recovery rates described for these tick species is also lower than 20\% (LABRUNA et al., 2003b; MARTINS et al., 2012; 2017). Nymphs of $A$. dubitatum, when submitted to feeding on Cavia porcellus, present a recovery rate of 36\% (LABRUNA et al., 2004a). This differed from results of the present study, which demonstrated a recovery rate higher than 50\%. Regarding engorging periods of larvae and nymphs of different cited tick species, results are similar amongst each other (LABRUNA et al., 2003b; 2004a; MARTINS et al., 2017) and corroborate with values obtained on this experiment.

The abovementioned colony management practices together with the use of rabbits as hosts for the larval stage may have caused death, especially for eggs and engorged larvae, because little is known about the dynamics of larval parasitism in this species. The low rate of recovery of engorged larvae demonstrated in the present study is also worth mentioning as it suggests that the rabbits were not adequate hosts for this instar stage. Data from Ogrzewalska et al. $(2009,2010)$ show that birds can serve as hosts but that this is not common, and only a few individuals of this tick species have been found parasitizing birds in two different study areas, including the Amazon in northern Brazil and the Atlantic rain forest region.

The nymphal stage was the only stage that was amenable to both the experimental host and the controlled temperature and humidity (LC), and this stage showed a high recovery rate in which the majority of individuals became engorged and later molted to adults. However, it is known that this instar stage shows non-selective parasitism and exploits a wide variety of hosts, including humans, even if only occasionally (BELDOMÉNICO et al., 2003; LABRUNA et al., 2005; SARAIVA et al., 2012; SPONCHIADO et al., 2015; GARCIA et al., 2015; OGRZEWALSKA \& PINTER, 2016; OGRZEWALSKA et al., 2009, 2010; ITO et al., 2017).

It is worth mentioning that despite the difficulties encountered in this study, the results are consistent and highly informative because until now nothing was known about the biological parameters related to the life cycle of $A$. coelebs. There has only been one previously published study regarding adult and nymphs ticks of this species parasitizing humans (BELDOMÉNICO et al., 2003; GARCIA et al., 2015).

On the basis of the biological parameters evaluated in this study, we can infer that the life cycle of $A$. coelebs maintained under partially NC and under LC can be completed in 187.45 and 149.53 days, respectively. Part of the knowledge gap concerning the biological 
parameters of this tick species under experimental conditions has been filled here; however, there is still a need for additional studies to better understand the influences of abiotic factors and host-related factors on the life cycle of this tick species.

\section{Acknowledgements}

We thank the Coordenação de Aperfeiçoamento de Pessoal de Nivel Superior (Capes), the Conselho Nacional de Desenvolvimento Científico e Tecnológico (CNPq), the Fundaçáo de Apoio ao Desenvolvimento do Ensino, Ciência e Tecnologia do Estado de Mato Grosso do Sul (Fundect, MS) - Governo do Estado de Mato Grosso do Sul and Embrapa Gado de Corte. We also thank the Fundação de Apoio ao Desenvolvimento do Ensino, Ciência e Tecnologia do Estado de Rondônia (Fapero-RO) - Governo do Estado de Rondônia and the Fundação Oswaldo Cruz/Fiocruz, Rondônia.

\section{References}

Arzua M, Onofrio VC, Barros-Battesti DM. Catalogue of the tick collection (Acari, Ixodida) of the Museu de História Natural Capão da Imbuia, Curitiba, Paraná, Brazil. Rev Bras Zool 2005; 22(3): 623-632. http://dx.doi.org/10.1590/S0101-81752005000300015.

Barros-Battesti DM, Arzua M, Bechara GH. Carrapatos de importância médico-veterinária da região Neotropical: um guia ilustrado para identificação de espécies. São Paulo: Vox/ICTTD-3/Butantan; 2006. 223 p.

Bechara GH, Szabó MPJ, Ferreira BR, Garcia MV. Rhipicephalus sanguineus tick in Brazil: feeding and reproductive aspects under laboratorial conditions. Rev Bras Parasitol Vet 1995; 4(2): 61-66.

Beldoménico PM, Baldi JC, Antoniazzi LR, Orduna GM, Mastropaolo M, Macedo AC, et al. Ixodid ticks (Acari: Ixodidae) present at Parque Nacional El Rey, Argentina. Neotrop Entomol 2003; 32(2): 273-277. http://dx.doi.org/10.1590/S1519-566X2003000200012.

Bennett GF. Oviposition of Boophilus microplus (Canestrini) (Acarina: Ixodidae). I. Influence of tick size on egg production. Acarologia 1974; 16(1): 52-61. PMid:4463680.

Garcia MV, Matias J, Aguirre AAR, Csordas BG, Szabó MPJ, Andreotti R. Successful feeding of Amblyomma coelebs (Acari: Ixodidae) nymphs on humans in Brazil: skin reactions to parasitism. J Med Entomol 2015; 52(2): 117-119. PMid:26336294. http://dx.doi.org/10.1093/jme/tju060.

Guglielmone AA, Mangold AJ, Garcia MD. The life cycle of Amblyomma parvum Aragão, 1908 (Acari, Ixodidae) under laboratory conditions. Exp Appl Acarol 1991; 13(2): 129-136. PMid:1786743. http://dx.doi. org/10.1007/BF01193663.

Guglielmone AA, Robbins RG, Apanaskevich DA, Petney TN, EstradaPeña A, Horak IG. The hard ticks of the world (Acari: Ixodida: Ixodidae). London: Springer; 2014

Guimarães JC, Tucci EC, Barros-Batestti DM. Ectoparasitos de importância veterinária. Sáo Paulo: Plêiade; 2001. 213 p.

Ito K, Taniguchi H, Ohtaki N, Ando S, Kawabata H. A first case of tick bite by Amblyomma coelebs in Japan. J Dermatol 2017: 1-2. PMid:28326613.

Karpathy SE, Slater KS, Goldsmith CS, Nicholson WL, Paddock CD. Rickettsia amblyommatis sp. nov., a spotted fever group Rickettsia associated with multiple species of Amblyomma ticks in North, Central and South America. Int J Syst Evol Microbiol 2016; 66(12): 5236-5243. PMid:27638476. http://dx.doi.org/10.1099/ijsem.0.001502.

Krawczak FS, Martins TF, Oliveira CS, Binder LC, Costa FB, Nunes PH, et al. Amblyomma yucumense n. sp. (Acari: Ixodidae), a Parasite of Wild Mammals in Southern Brazil. J Med Entomol 2015; 52(1): 28-37. PMid:26336277. http://dx.doi.org/10.1093/jme/tju007.

Labruna MB, Amaku M, Metzner JA, Pinter A, Ferreira F. Larval behavioral diapause regulates life cycle of Amblyomma cajennense (Acari: Ixodidae) in Southeast Brazil. J Med Entomol 2003a; 40(2): 170-178. PMid:12693845. http://dx.doi.org/10.1603/0022-2585-40.2.170.

Labruna MB, Fugisaki EYM, Pinter A, Duarte JMB, Szabó MJP. Life cycle and host specificity of Amblyomma triste (Acari: Ixodidae) under laboratory conditions. Exp Appl Acarol 2003b; 30(4): 305-316. PMid:14756395. http://dx.doi.org/10.1023/B:APPA.0000006514.02451.6d.

Labruna MB, Camargo LMA, Terrassini FA, Ferreira F, Schumaker TS, Camargo EP. Ticks (Acari: Ixodidae) from the state of Rondônia, western Amazon, Brazil. Syst Appl Acarol 2005; 10(0): 17-32. http:// dx.doi.org/10.11158/saa.10.1.4.

Labruna MB, Guglielmone AA. Ticks of New World tapirs. In: Traeholt C, editor. Tapir conservation. Houston: Zoo Inc.; 2009. p. 21-28.

Labruna MB, Kasai N, Ferreira F, Faccini JLH, Gennari MS. Seasonal dynamics of ticks (Acari: Ixodidae) on horses in the state of Sáo Paulo, Brazil. Vet Parasitol 2002a; 105(1): 65-77. PMid:11879967. http:// dx.doi.org/10.1016/S0304-4017(01)00649-5.

Labruna MB, Paula CD, Lima TF, Sana DA. Ticks (Acari: Ixodidae) on wild animals from the Porto Primavera Hydroelectric power station area, Brazil. Mem Inst Oswaldo Cruz 2002b; 97(8): 1133-1136. PMid:12563479. http://dx.doi.org/10.1590/S0074-02762002000800012.

Labruna MB, Leite RC, Faccini JLH, Ferreira F. Life cycle of the tick Haemaphysalis leporis-palustris (Acari: Ixodidae) under laboratory conditions. Exp Appl Acarol 2000; 24(9): 683-694. PMid:1 1227826. http://dx.doi. org/10.1023/A:1010768511790.

Labruna MB, Nava S, Marcili A, Barbieri AR, Nunes PH, Horta MC, et al. A new argasid tick species (Acari: Argasidae) associated with the rock cavy, Kerodon rupestris Wied-Neuwied (Rodentia: Caviidae), in a semiarid region of Brazil. Parasit Vectors 2016; 9(1): 511. PMid:27655282. http:// dx.doi.org/10.1186/s13071-016-1796-7.

Labruna MB, Pinter A, Teixeira RHF. Life cycle of Amblyomma cooperi (Acari: Ixodidae) using capybaras (Hydrochaeris hydrochaeris) as hosts. Exp Appl Acarol 2004a; 32(1-2): 79-88. PMid:15139274. http://dx.doi. org/10.1023/B:APPA.0000018228.05088.26.

Labruna MB, Whitworth T, Bouyer DH, McBride J, Camargo LMA, Camargo P, et al. Rickettsia bellii and Rickettsia amblyommii in Amblyomma ticks from the state of Rondonia, Western Amazon, Brazil. J Med Entomol 2004b; 41(6): 1073-1081. PMid:15605647. http://dx.doi. org/10.1603/0022-2585-41.6.1073.

Lopes MG, May L Jr, Foster RJ, Harmsen BJ, Sanchez E, Martins TF, et al. Ticks and rickettsiae from wildlife in Belize, Central America. Parasit Vectors 2016; 9(1): 62. PMid:26831147. http://dx.doi.org/10.1186/ s13071-016-1348-1.

Mangold AJ, Guglielmone AA. The life cycle of Amblyomma pseudoparvum (Acari: lxodidae) in the laboratory. Exp ApplAcarol 1993; 17(5): 377-380. http://dx.doi.org/10.1007/BF00058600.

Martins TF, Luz HR, Faccini JLH, Labruna MB. Life-cycle of Amblyomma oblongoguttatum (Acari: Ixodidae) under laboratory conditions. Exp Appl 
Acarol 2017; 71(4): 415-424. PMid:28493036. http://dx.doi.org/10.1007/ s10493-017-0135-9.

Martins TF, Moura MM, Labruna MB. Life-cycle and host preference of Amblyomma ovale (Acari: Ixodidae) under laboratory conditions. Exp Appl Acarol 2012; 56(2): 151-158. PMid:22113779. http://dx.doi. org/10.1007/s10493-011-9506-9.

Muñoz-Leal S, Toledo LF, Venzal JM, Marcili A, Martins TF, Acosta ICL, et al. Description of a new soft tick species (Acari: Argasidae: Ornithodoros) associated with stream-breeding frogs (Anura: Cycloramphidae: Cycloramphus) in Brazil. Ticks Tick Borne Dis 2017; 8(5): 682-692. PMid:28506539. http://dx.doi.org/10.1016/j.ttbdis.2017.04.015.

Nava S, Venzal JM, González-Acunã D, Martins TF, Guglielmone AA. Ticks of the Southern Cone of America: diagnosis, distribution, and hosts with taxonomy, ecology and sanitary importance. London: Elsevier; 2017.

Ogrzewalska M, Pacheco RC, Uezu A, Richtzenhain LJ, Ferreira F, Labruna MB. Ticks (Acari: Ixodidae) infesting birds in Atlantic rain forest region of Brazil. J Med Entomol 2009; 46(5): 1225-1229. PMid:19769058. http://dx.doi.org/10.1603/033.046.0534.

Ogrzewalska M, Pinter A. Ticks (Acari: Ixodidae) as ectoparasites of Brazilian wild birds and their association with rickettsial diseases. Braz J Vet Res Anim Sci 2016; 53(1): 1-31. http://dx.doi.org/10.11606/ issn.1678-4456.v53i1p1-31.

Ogrzewalska M, Uezu A, Labruna MB. Ticks (Acari: Ixodidae) infesting wild birds in the eastern Amazon, northern Brazil, with notes on rickettsial infection in ticks. Parasitol Res 2010; 106(4): 809-816. PMid:20140452. http://dx.doi.org/10.1007/s00436-010-1733-1.

Olegário MMM, Gerardi M, Tsuruta AS, Szabó MPJ. Life cycle of the tick Amblyomma parvum Aragáo, 1908 (Acari: Ixodidae) and suitability of domestic hosts under laboratory conditions. Vet Parasitol 2011; 179(1-3): 203-208. PMid:21353392. http://dx.doi.org/10.1016/j. vetpar.2011.01.056.

Oliveira PR, Borges LMF, Lopes CML, Leite RC. Population dynamics of the free-living stages of Amblyomma cajennense (Fabricius, 1787) (Acari: Ixodidae) on pastures of Pedro Leopoldo, Minas Gerais State, Brazil. Vet Parasitol 2000; 92(4): 295-301. PMid:10996741. http:// dx.doi.org/10.1016/S0304-4017(00)00322-8.

Onofrio VC, Venzal JM, Pinter A, Szabó MPJ. Família Ixodidae: Características gerais, comentários e chave para gêneros. In: Barros-Battesti DM, Arzua M, Bechara GH. Carrapatos de importancia médico-veterinária da regiāo Neotropical: um guia ilustrado para identificação de espécies. São Paulo: Vox/ICTTD-3/Butantan; 2006. p. 29-39.

Rechav Y. Dynamics of tick populations (Acari: Ixodidae) in the Eastern Cape province of South-Africa. J Med Entomol 1982; 19(6): 679-700. PMid:7154025. http://dx.doi.org/10.1093/jmedent/19.6.679.

Rodrigues DS, Carvalho HA, Fernandes AA, Freitas CMV, Leite RC, Oliveira PR. Biology of Amblyomma aureolatum (Pallas, 1772) (Acari:
Ixodidae) on some laboratory hosts in Brazil. Mem Inst Oswaldo Cruz 2002; 97(6): 853-856. PMid:12386709. http://dx.doi.org/10.1590/ S0074-02762002000600018.

Rodrigues VS, Garcia MV, Cruz BC, Maciel WG, Zimmermann NP, Koller WW, et al. Life cycle and parasitic competence of Dermacentor nitens Neumann, 1897 (Acari: Ixodidae) on different animal species. Ticks Tick Borne Dis 2017; 8(3): 379-384. PMid:28063831. http:// dx.doi.org/10.1016/j.ttbdis.2016.12.014.

Sanches GS, Bechara GH, Garcia MV, Labruna MB, Szabó MPJ. Biological aspects of Amblyomma brasiliense (Acari: Ixodidae) under laboratory conditions. Exp Appl Acarol 2008; 44(1): 43-48. PMid:18188669. http:// dx.doi.org/10.1007/s10493-007-9127-5.

Saraiva DG, Fournier GF, Martins TF, Leal KP, Vieira FN, Câmara EM, et al. Ticks (Acari: Ixodidae) associated with small terrestrial mammals in the state of Minas Gerais, southeastern Brazil. Exp Appl Acarol 2012; 58(2): 159-166. PMid:22585005. http://dx.doi.org/10.1007/s10493012-9570-9.

Silveira I, Martins TF, Olegário MM, Peterka C, Guedes E, Ferreira F, et al. Rickettsial infection in animals, humans and ticks in Paulicéia, Brazil. Zoonoses Public Health 2015; 62(7): 525-533. PMid:25643912. http://dx.doi.org/10.1111/zph.12180.

Sponchiado J, Melo GL, Martins TF, Krawczak FS, Labruna MB, Cáceres NC. Association patterns of ticks (Acari: Ixodida: Ixodidae, Argasidae) of small mammals in Cerrado fragments, western Brazil. Exp Appl Acarol 2015; 65(3): 389-401. PMid:25633262. http://dx.doi.org/10.1007/ s10493-014-9877-9.

Szabó MPJ, Mukai LS, Rosa PCS, Bechara GH. Differences in the acquired resistance of dogs, hamsters, and guinea pigs to repeated infestations with adult ticks Rhipicephalus sanguineus (Acari: Ixodidae). Braz J Vet Res Anim Sci 1995; 32(1): 43-50.

Szabó MPJ, Pereira LF, Castro MB, Garcia MV, Sanches GS, Labruna MB. Biology and life cycle of Amblyomma incisum (Acari: Ixodidae). Exp Appl Acarol 2009; 48(3): 263-271. PMid:19130270. http://dx.doi. org/10.1007/s10493-008-9234-y.

Tatchell RJ. Interactions between ticks and their hosts. Int J Parasitol 1987; 17(2): 597-606. PMid:3294670. http://dx.doi.org/10.1016/00207519(87)90136-6.

Troughton DR, Levin MLL. Life Cycles of Seven Ixodid Tick Species (Acari: Ixodidae) Under Standardized Laboratory Conditions. J Med Entomol 2007; 44(5): 732-740. PMid:17915502. http://dx.doi.org/10.1093/ jmedent/44.5.732.

Wolf RW, Aragona M, Muñoz-Leal S, Pinto LB, Melo ALT, Braga IA, et al. Novel Babesia and Hepatozoon agents infecting non-volant small mammals in the Brazilian Pantanal, with the first record of the tick Ornithodoros guaporensis in Brazil. Ticks Tick Borne Dis 2016; 7(3): 449456. PMid:26782931. http://dx.doi.org/10.1016/j.ttbdis.2016.01.005. 